\title{
SETTLEMENTS OF SOUTH TRANSDANUBIA IN THE LIGHT OF A
} NATIONAL MARKET SURVEY

\section{DÉL-DUNÁNTÚLI TELEPÜLÉSEK EGY ORSZÁGOS PIACKUTATÁS TÜKRÉBEN}

Zoltán KOLTAI, Dr. Ph.D, associate professor University of Pécs

Address: $\quad$ 1/B. Szántó K. J. str. Pécs H-7633

Phone: $\quad+3672 / 501-500 / 22547$

E-mail: $\quad$ koltai.zoltan@feek.pte.hu 


\title{
DÉL-DUNÁNTÚLI TELEPÜLÉSEK EGY ORSZÁGOS PIACKUTATÁS TÜKRÉBEN
}

\section{SETTLEMENTS OF SOUTH TRANSDANUBIA IN THE LIGHT OF A NATIONAL MARKET SURVEY}

Keywords: competitiveness, residential attractions, settlement hierarchy, South Transdanubia, Pécs

\begin{abstract}
Summary
We made a layered questionnaire survey in 2004-2005. We wanted to find the answer to the following questions: What aspects do Hungarian citizens prefer when choosing their place of residence? What characteristics, advantages and disadvantages do they use to describe the settlement types of different size? Which Hungarian settlements are considered competitive by the respondents and why? Which are the settlements that the stakeholders see as real centres of gravity? How much are the respondents willing to move to another settlement? In the light of the results, we repeated our survey of the population in 20122013 , allowing thereby the comprehensive evaluation of a period of almost ten years. In this phase of data recording we used the method of a layered questionnaire survey again, in which it was one thousand private persons again who responded to our questions.
\end{abstract}

Kulcsszavak: versenyképesség, lakóhelyi vonzerök, településrangsor, Dél-Dunántúl, Pécs

\section{Összefoglaló}

2004-2005-ben rétegzett kérdőíves kutatást végeztünk, melynek keretében ezer magánszemély és szintén ezer vállalatvezető adott választ a magyarországi települések versenyképességével kapcsolatos kérdéseinkre. A kapott eredmények tükrében 2012-2013-ban megismételtük lakosságra vonatkozó vizsgálatunkat (vállalatokra vonatkozó újabb kutatásunk még nem valósult meg), lehetőséget teremtve ezzel a közel egy évtizedes időszak átfogó értékelésére.

A versenyképesség, sikeresség értelmezése a kutatás során nem korlátozódik a fogalom kizárólag gazdasági megközelítésére, hanem annál tágabban, komplex módon, egyaránt értjük alatta a társadalmi és környezeti szempontokat, az általában vett életminőséget.

Az általunk vizsgált témakörök felölelték a lakóhelyi vonzerök értékelését, országos és regionális települési rangsorok felállítását, a legsikeresebbnek gondolt városok vonzerejének vizsgálatát országos és regionális léptékben, a lakóhely potenciális megváltoztatásának okait és annak területi jellegzetességeit, valamint a különbözö településtípusok, mint lakóhelyek megítélését.

Jelen tanulmányban, ahogy erre a cím is utal, mindössze a kutatás bizonyos részeredményeinek közlésére vállalkozunk, ami egyrészt az elemzett témák közötti szelekcióban, másrészt a kapott eredmények DélDunántúlra történő leszükítésében mutatkozik meg.

\section{BEVEZETÉS}

A versenyképesség mérésének tulajdonképpeni célja az, hogy a városok helyzetét reálisan meg tudjuk ítélni és ezek alapján a fejlődés elősegítéséhez szükséges legfontosabb teendőket át tudjuk tekinteni.

Mindig fontos megtalálni, hogy egy város miben különbözik a hasonló méretű és funkciójú többi várostól. A városversenyben nagyon sok hasonló adottságú város vesz 
részt, emiatt valamilyen vonatkozásban ki kell tünni közülük. Amennyiben elfogadjuk, hogy a területi verseny célja a térségben élők jólétének fokozása a magas foglalkoztatottságon, a megtermelt jövedelem tartós emelkedésén keresztül, azt is kijelenthetjük, hogy versenyben való sikeres helytállás eszköze egy speciális, ugyanakkor rugalmasan módosítható, az önkormányzatok, civilek és dinamikus vállalati hálózatok által koordinált gazdaságfejlesztési program, melyet az érintett háztartások, vállalkozások ismernek, és egyben támogatnak is.

A sikeressé válásban a mérhető kategóriák mellett hasonlóan fontos szerepet játszanak a nem mérhető jellemzők, gondoljunk például a helyi adminisztráció hatékony müködésére, az üzleti szolgáltatások színvonalára vagy a szociális infrastruktúra szerepére (Boddy, 2002). Az ilyen települések jellemzői egyébként meglehetősen széles skálán mozognak, rugalmasan változtatható gazdasági szerkezetüktől kezdve, a magasan kvalifikált munkaerőn és a kedvező társadalmi szerkezeten keresztül, egészen értékes településkörnyezetükig (Enyedi 1997, Jensen-Butler 1997, Cheshire 1999).

Azok az európai városok tudtak sikeressé válni, amelyek képesek voltak saját endogén adottságaikra épülő fejlesztési stratégiát meghatározni és müködtetni. Ezzel szemben az önálló programalkotásra képtelen települések, ahol a vezető ágazatok versenyképességének romlását nem követte egy diverzifikált fejlesztés, legfeljebb átmenetileg stabilizálhatták helyzetüket, azt is csak többnyire központi támogatások felhasználásából. Az ilyen települések növekedési potenciája és versenyképessége csekély, a nemzetközi területi munkamegosztásba való bekapcsolódásuk meglehetősen esetleges (Horváth, 1998).

„A versenyképesség mindig a tényezők kombinációjától függ, de nincs garancia a sikerre, mindegyik városban helyben kell kitalálni és megvalósítani a fejlesztési stratégiákat a többi hasonló helyzetű várossal versengve.” (Lengyel, 2003, 273. o.)

A kutatás célja, pontosan egy ilyen jól átgondolt, a valós helyi igényekre alapozott stratégia kidolgozásához nyújtandó információ, amely jól érzékelteti, hogy a különböző országrészek és települések nem csak különböző adottságokkal, relatíve nagyon eltérő pozícióval, de sokszor meglehetősen differenciált igényekkel és tapasztalatokkal is rendelkező lakónépességgel és vállalatokkal jellemezhetők. 


\section{ANYAG ÉS MÓDSZER}

2004-2005-ben rétegzett kérdőíves kutatást végeztünk, melynek keretében ezer magánszemély adott választ a települések versenyképességével kapcsolatos kérdéseinkre (Koltai 2005, 2006, 2008).

A közel tíz évvel ezelőtti kutatás keretében az alábbi kérdésekre kerestünk választ:

- Milyen szempontokat részesít előnyben a magyar lakosság lakóhelyének megválasztásakor?

- Melyik magyarországi településeket és miért tartják versenyképesnek a válaszadók?

- Milyen költözési hajlandóság jellemzi a megkérdezetteket?

- Melyek azok a települések, melyeket valódi vonzásközpontoknak tartanak az érintettek?

- Milyen jellemzőkkel, előnyökkel és hátrányokkal írják le a különböző településtípusokat?

A kapott eredmények tükrében 2012-2013-ban megismételtük lakosságra vonatkozó vizsgálatunkat, lehetőséget teremtve ezzel a közel egy évtizedes időszak átfogó értékelésére (vállalatokra vonatkozó újabb kutatásunk még nem valósult meg). Az adatfelvétel ezen második fázisában szintén rétegzett kérdőíves megkereséseket folytattunk (a figyelembe vett négy szempont: a magyarországi népesség régiók szerinti megoszlása, a lakosság nemek, korcsoportok és végül iskolai végzettség szerinti tagozódása volt), melynek eredményeként újból ezer magánszemély adott választ kérdéseinkre.

A kutatási eredmények közlése előtt fontosnak tartom rögzíteni, hogy a 2012-2013-as adatfelvétel során a 2004-2005-ös kutatáshoz képest valamivel magasabb volt az 5.00050.000 fő közötti lélekszámú, valamint 50.000 főnél népesebb településen élő válaszadók aránya, ami értelemszerüen a mintába kerülő, 5000 fő alatti települések korábbinál kisebb elemszámú előfordulását okozta. Erre a tényre a kapott eredmények összevetése során többször utalunk.

Vizsgálatunk most is törekedett a témakörben született, alapvetően statisztikai adatokon nyugvó kutatásokkal történő összehasonlíthatóság biztosítására (a teljesség igénye nélkül, előző adatfelvételünk óta megjelent kutatások közül válogatva: Csabina - Leveleki 2006, Lukovics 2006, Molnár 2006, Ambrus - Kissné - Kólyáné - Malakucziné 2008, Lukovics - Kovács 2008, Berényi 2009, Jakobi 2010, Lukovics - Lóránd 2010, Makra - Sümeghy 2010, Nagyházi - Vanyó 2010, Lampertné 2010, Tánczos 2010, Grosz 2011, Lukovics - 
Kovács 2011, Makszim 2011, Bodnár 2012, Farkas 2012, Csomós 2013, Tóth - Nagy 2013, Tóth 2014).

\section{EREDMÉNYEK}

Megismételt vizsgálatunk keretében a települések vonzerejét alakító, korábbi 12 szempontot 20 tagúra bővítettük. Ezt két okból véltük indokoltnak. Egyrészt figyelembe vettük a 2004-2005-ös vizsgálat „egyéb” kategóriájában, nagyobb arányban szereplő tényezőket (így önálló kategóriaként megjelent a „lakosság etnikai összetétele”, valamint a „település közbiztonsága”), másrészt kíváncsiak voltunk arra, hogy három korábbi, meglehetősen heterogén tartalmú tényezőt (települési infrastruktúra, oktatási viszonyok, városi szerepkörök szélessége) részekre bontva, milyen többletinformációhoz juthatunk.

Ebből a megfontolásból a megelőző kutatás legfontosabbra értékelt „települési infrastruktúra" kategóriáját négy elemre bontottuk (gázszolgáltatás, csatornázottság, internetelérés-mobilhálózat, közúthálózat), a korábbi „oktatási viszonyok” pedig kiegészült egy plusz tényezővel (,az óvodai és alapfokú oktatás megléte”). Ezen kívül a „városi szerepkörök szélessége" szempontot már két külön kategóriaként értelmeztük (külön-külön vizsgálva az „ügyintézési lehetőségek meglétét” és a „kereskedelmi hálózat fejlettségét”).

2004-2005-ös kutatási eredményeinkre alapozva, hipotézisünk az volt, hogy továbbra is kiemelten fontos vonzerőnek számít a „települési infrastruktúra állapota”, a „közlekedési adottságok”, a „foglalkoztatási körülmények”, a „helyben igénybe vehető egészségügyi szolgáltatások szélessége” és általában véve a „lakókörnyezet állapota” (Koltai 2005, 2006).

2012-2013-as adataink kiértékelésekor (lásd 1. ábra) a legmagasabb értéket a „település közbiztonsága” tényező kapta $(4,45)$, amit a „település infrastrukturális ellátottsága” $(4,37)$, a „lakókörnyezet állapota” $(4,32)$ és az „egészségügyi szolgáltatások teljessége” $(4,27)$ követ. Az ötfokozatú skálán még további négy tényező szerepelt 4 feletti értékkel, ezek a foglalkoztatási lehetőségek és körülmények, az óvodai és alapfokú oktatás megléte, a közlekedési kapcsolatok és végül az ügyintézési lehetőségek megléte.

Vagyis az oktatási adottságokon belül egyértelműen felértékelődött az óvodai és alapfokú oktatás szerepe (a korábbi kutatásunkban még egységes kategóriaként szereplő „oktatási viszonyok” $(3,83)$ ezúttal már két markánsan elkülönülő részre bomlott), a „városi szerepkörök” felosztása pedig arról informált bennünket, hogy az ügyintézési lehetőségek, közintézmények megléte valamivel fontosabb a válaszadók számára, mint a 
települések kereskedelmi ellátottsága. Emellett kismértékben nőtt a lakókörnyezet állapotára és az egészségügyi szolgáltatásokra adott pontérték.

A „települési infrastruktúra” kategóriájának négy részre bontása (gázszolgáltatás, csatornázottság, internetelérés-mobilhálózat, közúthálózat) nem eredményezett lényeges differenciákat, mivel az értékek a 4,01-4,35 közötti tartományban szóródnak. Közülük a legmagasabb értéket a csatornázottság megléte, míg a legalacsonyabbat a közúthálózat minősége kapta.

A lakóhelyi vonzerők alacsonyabbra értékelt, második csoportját szintén egy új tényező, a „lakosság etnikai összetétele” vezeti $(3,85)$, míg korábbi kutatásunkkal megegyezően a sort a „lakosság korösszetétele” és a „település történelme, hagyományai, helyi tradíciók” zárják. A korábbiakhoz képest kismértékben felértékelődtek a „település természeti adottságai", míg az egyéb kategóriában értékelhető módon egyedül a családi, baráti kapcsolatok tényező szerepel (igaz, alig kimutatható, nem egészen 2 százalékos előfordulással).

Hipotézisünk teljesülése azért mondható részlegesnek, mert a település közbiztonsága, mint települési vonzerő nem várt módon került az első helyre.

1. ábra: A települési vonzerők fontossági sorrendje a magyar lakosság megkérdezése alapján, 2012-2013

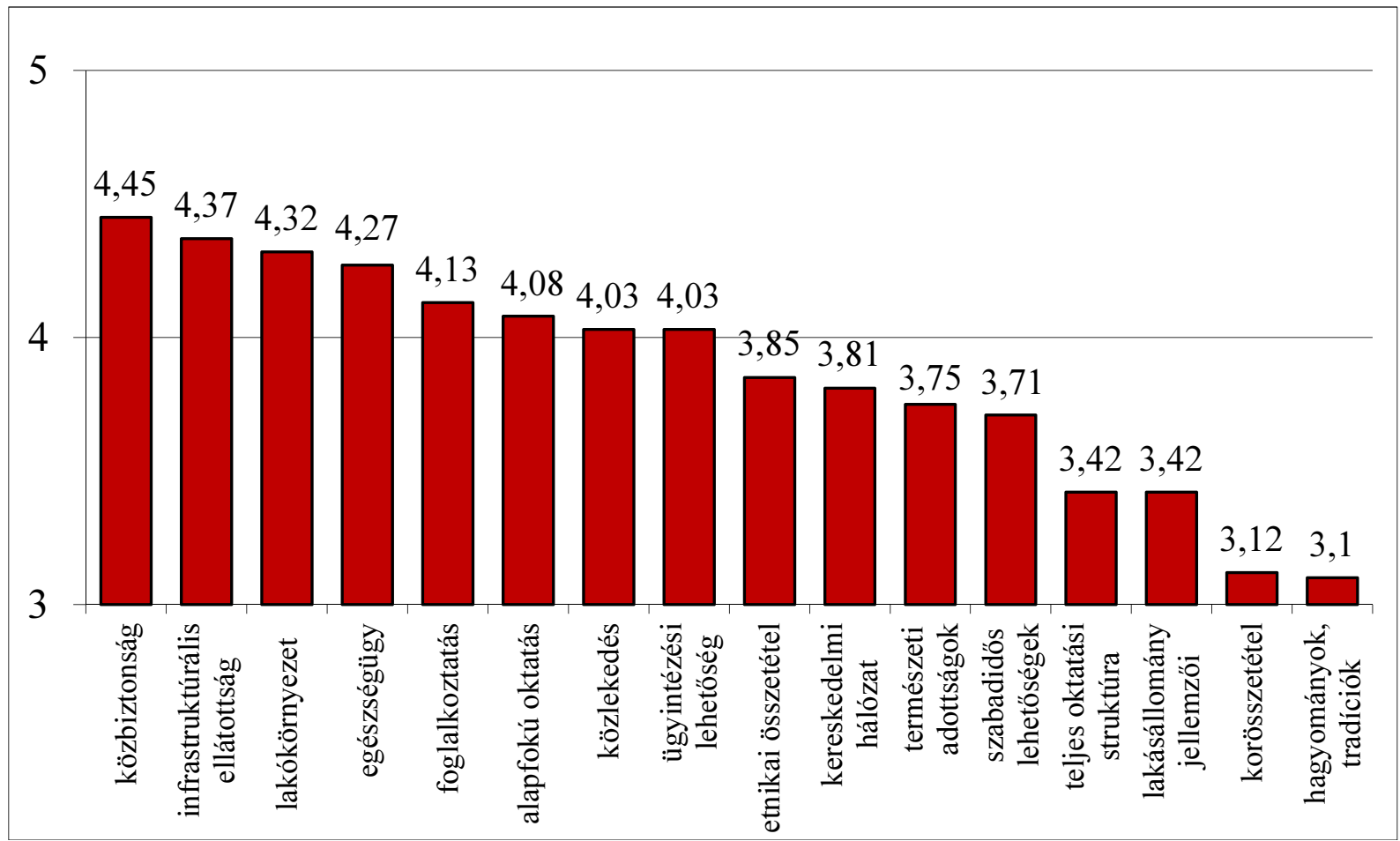

Kérdésünk: „Mennyire jelentenek Önnek vonzerőt egy település esetében az alábbi tényezők? Pontozza 1-től 5-ig az egyes tényezőket!"

Forrás: Saját kérdőíves felmérés (2012-2013) 
Regionális versenyképességi sorrendek

2004-2005-ös kutatásunkhoz hasonlóan a kérdőívek második és harmadik kérdésével egyrészt országos és regionális településrangsorok felállítására nyílt lehetőségünk, másrészt kimutathatóvá váltak az egyes települések karakterisztikus jellemzői, azok országos és régión belüli megítélésének hasonlóságai vagy éppen különbözőségei.

Nyitott formában megfogalmazott kérdésünkre (,Sorolja fel (maximum 5-öt) az Ön szerint versenyképes településeket!"), bármilyen magyarországi települést megadhattak a válaszadók. Fenntartottuk azt a korábbi hipotézisünket, miszerint Magyarországon a versenyképesség és a településhierarchiában elfoglalt pozíció között igen szoros kapcsolat mutatható ki, ezért továbbra is a hazai közép- és nagyvárosok számítanak a leginkább versenyképeseknek. A hierarchia alacsonyabb szintjein elhelyezkedő településeket kedvező regionális elhelyezkedésük vagy speciális adottságaik emelhetik a versenyképesség egy következő szintjére.

Az 1000 fős minta alapján, az előfordulás gyakorisága szerint az alábbi sorrendet kaptuk (az 1. számú táblázatban csak a válaszok legalább 5\% -át meghaladó településeket tüntettük fel, a súlyozás pedig hasonlóan a korábbiakhoz, az egy kérdőívben szereplő települések említési sorrendjét vette alapul 1-töl 5-ig, de ahogy látszik, ez csak a rangsor második felében okozott minimális változásokat).

1. táblázat: Versenyképes települések sorrendje a magyar lakosság megkérdezése alapján, 2012-2013

\begin{tabular}{|c|c|c|c|}
\hline Ssz. & Település & Említések száma & Súlyozott említés \\
\hline 1. & Budapest & 823 & 3726 \\
\hline 2. & Györ & 449 & 1509 \\
\hline 3. & Debrecen & 395 & 1229 \\
\hline 4. & Pécs & 367 & 1034 \\
\hline 5. & Szeged & 339 & 943 \\
\hline 6. & Sopron & 239 & 733 \\
\hline 7. & Székesfehérvár & 170 & 502 \\
\hline 8. & Kecskemét & 129 & 364 \\
\hline 9. & Eger & 110 & 301 \\
\hline 10. & Miskolc & 85 & 219 \\
\hline 11. & Veszprém & 84 & 242 \\
\hline 12. & Szombathely & 67 & 170 \\
\hline 13. & Szolnok & 52 & 176 \\
\hline 14. & Nyíregyháza & 50 & 150 \\
\hline
\end{tabular}

Forrás: Saját kérdőíves felmérés (2012-2013) 
További sorrend a legalább 2\%-os említési határt elért településeknél: Siófok, Kaposvár, Zalaegerszeg, Keszthely, Hévíz, Esztergom, Balatonfüred, Budaörs.

Ahogy az 1. számú táblázatból is látszik, az 5\%-os említési határt egy nemmegyeszékhely (Sopron) haladta meg, de az első húszban is csak négy ilyen város szerepel (Sopronon kívül Siófok, Keszthely, Hévíz és Esztergom, melyek közül Siófok és Hévíz a 2004-2005-ös kutatásban is hasonlóan kedvező pozícióban szerepelt).

Továbbra is kiugróan magas a Budapestre adott válaszok aránya. A főváros első helyes említése a korábbi 410-ről 624-re emelkedett, és egyértelműen kijelenthető, hogy továbbra is külön kategóriát képvisel a versenyképesnek gondolt magyarországi települések körében.

A négytagú második csoportot Győr és Debrecen vezeti, Péccsel és Szegeddel kiegészülve. A közel tíz évvel korábbi adatfelvételhez képest lényegi változás, hogy Győr és Debrecen az átlagnál nagyobb mértékben erősítette meg pozícióját (ennek is tudható be rangsorbeli előrelépésük több helyezéssel), és míg Szeged megőrizte helyét, addig Pécs és Sopron valamivel hátrébb szorult (Koltai 2005, 2006). Utóbbi város mintegy átmenet képez a Székesfehérvár, Kecskemét, Eger hármashoz. Ha visszatekintünk a 2004-2005-ös adatokhoz, azt látjuk, hogy mostanra Kecskemét felzárkózott a másik két városhoz, Székesfehérvár helyzete állandó, Eger viszont a táblázatban szereplő városok közül egyedüliként, kevesebb említést kapott, mint korábbi adatfelvételünknél. Ahogy 20042005-ben, most is külön csoportot képez Miskolc, Veszprém és Szombathely, kiegészülve Szolnokkal és Nyíregyházával.

Hipotézisünk abból a szempontból is teljesült, hogy a következő szintet csakugyan olyan települések alkotják (néhány további megyeszékhelyen kívül Siófok, Keszthely, Hévíz, Esztergom, Balatonfüred, Budaörs), melyek csakugyan kedvező regionális elhelyezkedéssel vagy egyéb speciális adottságokkal bírnak.

Újból hangsúlyozzuk, hogy bár a 2012-2013-as adatfelvétel során a 2004-2005-ös kutatáshoz képest valamivel magasabb volt az 5.000-50.000 fő közötti lélekszámú, valamint 50.000 fönél népesebb településen élő válaszadók száma, ez önmagában nem magyarázza Budapest első helyes említéseinek ilyen mértékü növekedését és a nagyvárosok sorrendjében beállt változásokat sem. Az viszont tény, hogy mindez hozzájárulhatott ahhoz, hogy még markánsabban kiemelkedjenek a közép- és nagyvárosok a többi település köréből, felerősítve ezzel a versenyképességi rangsorban elért egyébként is kedvezőbb pozícióikat. 
A 2004-2005-ös kutatás régiókra lebontott rangsorai alapján mostani vizsgálatunknál azt a hipotézist fogalmaztuk meg, hogy minden egyes régióban felértékelődnek a szükebben vett környezet települései, és emiatt a leginkább versenyképesnek gondolt települések listáin több saját és szomszédos régióbeli város is helyet kap. Mindennek természetes következményeként az ország távolabbi pontjai a földrajzi távolsággal egyenes arányban hátrébb kerülnek a regionális rangsorokon.

2. táblázat: Versenyképes települések sorrendje a dél-dunántúli régió lakosságának válaszai alapján, 2012-2013

\begin{tabular}{|c|c|c|c|}
\hline Ssz. & Település & Említések száma & Súlyozott említés \\
\hline 1. & Budapest & 82 & 361 \\
\hline 2. & Pécs & 61 & 175 \\
\hline 3. & Győr & 46 & 163 \\
\hline 4. & Szeged & 37 & 84 \\
\hline 5. & Sopron & 32 & 103 \\
\hline 6. & Debrecen & 28 & 85 \\
\hline 7. & Kaposvár & 23 & 74 \\
\hline 8. & Székesfehérvár & 19 & 54 \\
\hline 9. & Veszprém & 12 & 36 \\
\hline 10. & Szombathely & 9 & 25 \\
\hline 11. & Kecskemét & 8 & 18 \\
\hline 12. & Zalaegerszeg & 7 & 13 \\
\hline 13. & Miskolc & 6 & 13 \\
\hline
\end{tabular}

Forrás: Saját kérdőíves felmérés (2012-2013)

A Dél-Dunántúl esetében megerősítést nyert hipotézisünk (lásd 2. számú táblázat), hiszen nemcsak Pécs került az előkelő második helyre (2004-2005-ben még első helyezett volt a régióbeli válaszok alapján a baranyai megyeszékhely), hanem felkerült a listára Kaposvár is, ahogy több dunántúli város (Sopron, Veszprém, Szombathely, Zalaegerszeg) javított országos pozícióján. Ellenben korábbi kutatásunkhoz képest több középváros (így Nagykanizsa, Szekszárd, Baja) hiányzik a dél-dunántúli listáról. Az Észak- és Dél-Alföld, valamint Észak-Magyarország városai szinte kivétel nélkül hátrébb szorultak (közülük is leginkább Debrecen).

Amennyiben a három szomszédos régiót is szemügyre vesszük, kiderül, hogy a NyugatDunántúlon Budapestet szorosabban követi Györ, javult a dunántúli városok pozíciója (Pécs, Sopron, Zalaegerszeg, Szombathely), valamint felkerült a listára a régióból 
Nagykanizsa, Keszthely és Zalakaros is. A Közép-Dunántúlon szintén javult Székesfehérvár, Veszprém és Pécs megítélése, ahogy a válaszadók több üdülővárost is a versenyképes települések közé soroltak, így Keszthelyt, Velencét, Balatonfüredet, Hévízt és Gárdonyt is. A Dél-Alföldön a fővárost követő második helyre Szeged került, megőrizte pozícióját Debrecen, az országos listához képest viszont hátrébb került Győr, Sopron, Szombathely, Eger, Miskolc és Nyíregyháza, Pécs pozíciója változatlan, míg ha alacsony értékkel is, de megjelent Baja és Siófok.

A városok vonzerejének megítélése országos és regionális léptékben

Korábbi kutatásunkhoz hasonlóan most is érdekes elemzési szempontnak ígérkezett annak vizsgálata, hogy egy adott várost hogyan ítélnek meg a válaszadók országosan és saját régióján belül. 2004-2005-ös eredményeink tükrében hipotézisünk az volt, hogy a saját régióján belül szinte mindegyik település, szinte minden szempont alapján kedvezőbb megítélést élvez, mint teszi azt országosan. (A korábbi adatfelvétel során a kivételek egyike Sopron volt. Koltai 2005, 2006.)

Mostani kutatásunk során, az alábbi módon elemeztük a kapott adatokat:

minden település esetén összehasonlítottuk az országos minta 1000 válaszadójának véleményét az adott város régióbeli válaszaival, ennek eredményeként kirajzolódtak az egyes települések karakterisztikus jegyei (az ábrákban „országos” és „regionális” jelöléssel),

másrészről leszükítettük a vizsgálatot azokra a válaszadókra, akik versenyképesnek gondolják az adott települést, ezzel a „versenyképes válaszok” megoszlását tettük vizsgálat tárgyává, másként fogalmazva kerestük az országosan vagy regionálisan felülértékelt tényezőket (,versenyképes országos”, „versenyképes regionális” megjegyzéssel),

időbeni összehasonlítást is végeztünk, melynek keretében a közel 10 évvel ezelőtti bázisadatokat állítottuk párhuzamba az aktuális adatokkal, folyamatában szemlélve a változásokat. 
2. ábra: Pécs megítélése a magyar lakosság megkérdezése alapján, 2012-2013

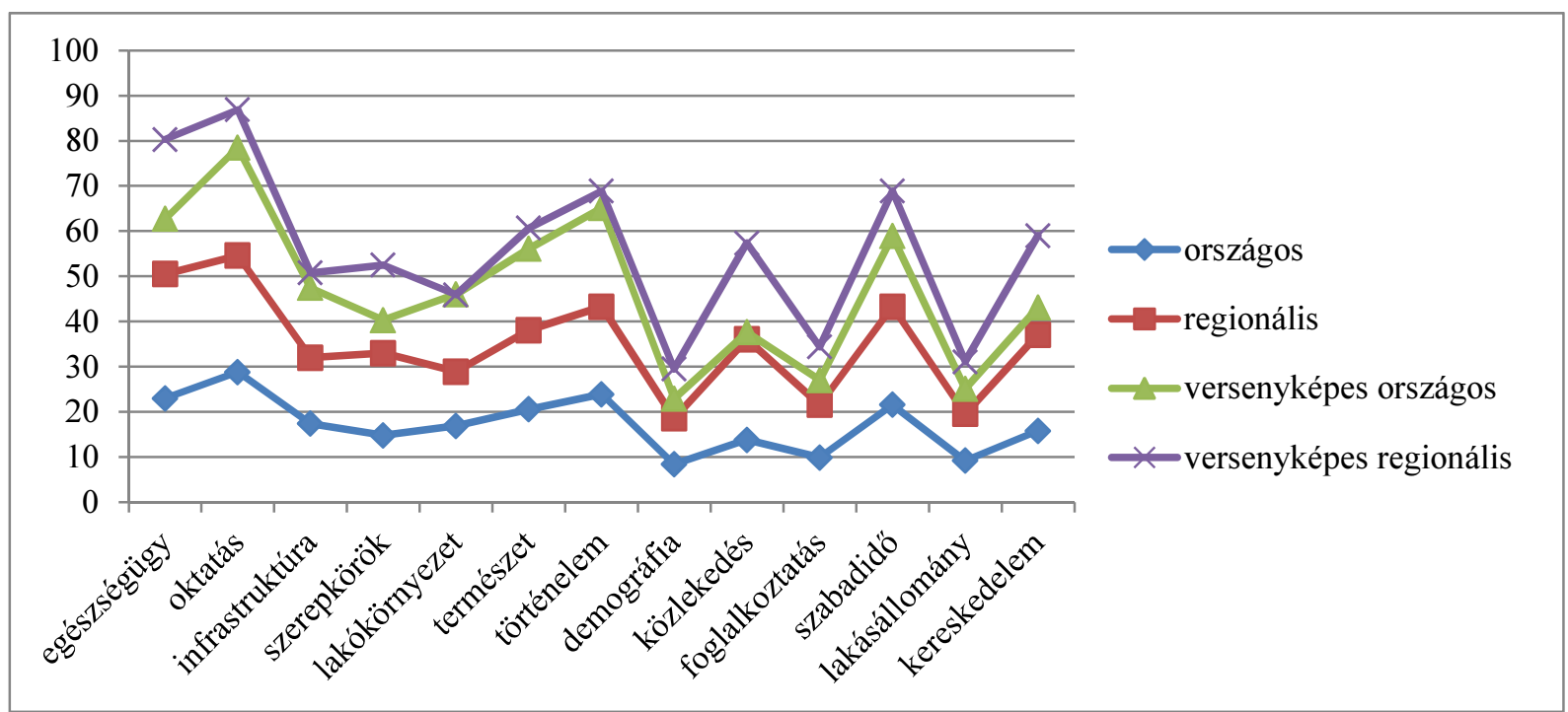

Kérdésünk: „Jelölje meg azokat a tényezőket, melyek esetében az adott település Ön szerint kiemelkedik az átlagból!"”

Forrás: Saját kérdőíves felmérés (2012-2013)

Pécs esetében az alábbi megállapításokat tehetjük:

- országos megítélését tekintve a város sorrendben a következő öt tényezőben mutat karakteres versenyképességi jegyeket: oktatási struktúra, a település történelme, egészségügyi szolgáltatások, szabadidős lehetőségek és természeti adottságok,

- a dél-dunántúli régióban mindezek kiegészülnek további kettő tényezővel (közlekedési kapcsolatok, kereskedelmi hálózat), és hipotézisünknek megfelelően az országosnál jóval gyakrabban (többször 20 százalékpontot meghaladó mértékű a növekedés) szerepelnek az egyes tényezők a válaszok között (ahogy a 2. számú ábrán is látható, például míg országosan a megkérdezettek 23 \%-a tartja kiemelkedőnek Pécs egészségügyi szolgáltatásait, a Dél-Dunántúlon már minden második válaszadó gondolja ugyanezt),

- 2004-2005-ös bázisadatainkhoz képest kijelenthető, hogy a régión belül a foglalkoztatási körülményeket kevesebben említik a versenyelőnyök között, de a többi tényező esetében is inkább stagnálásról, kismértékü visszaesésről árulkodnak a regionális adatok, pozitív változást abban találunk, hogy országosan 5-10 százalékponttal többen jelölnek meg egyes tényezőket (oktatási struktúra, a város történelme, egészségügy, szabadidős lehetőségek) a vonzerők sorában,

- a Pécset versenyképesnek tartó válaszokat elemezve megállapíthatjuk, hogy a közlekedési kapcsolatok, az egészségügy, a kereskedelmi hálózat fejlettsége és a városi 
szerepkörök szélessége jelentősen felülértékelt kategóriák a régióban, de kisebb mértékben a szabadidős lehetőségek is ide sorolhatók,

- Debrecen, Szeged és Pécs mind az országosan említett jellemzők (oktatási struktúra, egészségügyi szolgáltatások, szabadidős lehetőségek), mind az ezeket kiegészítő regionális karakterek szerint közel azonos megítélés alá esik, sőt a regionális felülértékeltség is hasonlóságot mutat, de az időbeni összevetésben egyértelmüen Debrecen értékei javultak a legdinamikusabban, míg Pécsnél több tényező értéke stagnál vagy romlik a 2004-2005-ös adatokhoz képest.

\section{KÖVETKEZTETÉSEK}

A magyar lakosság számára továbbra is kiemelten fontos lakóhelyi vonzerőnek számít a települési infrastruktúra állapota, a lakókörnyezet, a helyben igénybe vehető egészségügyi szolgáltatások megléte és a foglalkoztatási körülmények, de mindezeket megelőzi a település közbiztonsága.

Magyarországon a versenyképesség és a városok településhierarchiában elfoglalt pozíciója között igen szoros kapcsolat mutatható ki, a válaszadók szerint továbbra is a hazai közép- és nagyvárosok számítanak a leginkább versenyképeseknek. A hierarchia alacsonyabb szintjein elhelyezkedő városokat kedvező regionális elhelyezkedésük vagy speciális adottságaik emelhetik a versenyképes települések egy következő szintjére.

Minden egyes régióban felértékelődnek a szükebben vett környezet települései, és emiatt a leginkább versenyképesnek gondolt települések listáin több saját és szomszédos régióbeli város is helyet kapott. A Dél-Dunántúl esetében nemcsak Pécs került az előkelő második helyre, hanem több dunántúli város is javított országos pozícióján. Bár egyértelmüen kijelenthető, hogy Pécs továbbra is a régió legversenyképesebbnek gondolt települése, de több tényező esetében inkább stagnálásról, kismértékű visszaesésről árulkodnak adatai, az időbeni összevetésben pedig lemaradni látszik több hazai regionális központunktól.

A kutatás egyik célja a valós helyi igényeken alapuló fejlesztési stratégia kidolgozásához nyújtandó információ volt. Természetesen tisztában vagyunk azzal, hogy a részletes elemzésnek alávetett települési vonzerők egy jelentős csoportja nem kizárólagosan a helyi döntéshozóktól függ, a kedvező irányú változásokhoz pedig gyakran csak hosszú távú programok vezethetnek el. Ezzel együtt úgy gondoljuk, hogy a 
specifikus, esetleg konkrét települési célcsoportokat érintő fejlesztési elképzelések nem nélkülözhetik a személyes tapasztalatok mindenkori figyelembevételét.

\section{SUMMARY}

We made a layered questionnaire survey in 2004-2005, in the framework of which we received replies from one thousand private persons and also one thousand business leaders to our question relating to the competitiveness of Hungarian towns and cities (Koltai 2005, 2006, 2008).

This research conducted almost ten years ago sought the answer to the following questions:

- What aspects do Hungarian citizens prefer when choosing their place of residence?

- Which Hungarian settlements are considered competitive by the respondents and why?

- How much are the respondents willing to move to another settlement?

- Which are the settlements that the stakeholders see as real centres of gravity?

- What characteristics, advantages and disadvantages do they use to describe the different settlement types?

In the light of the results, we repeated our survey of the population in 2012-2013 (our new research of the business sector has not been conducted yet), allowing thereby the comprehensive evaluation of a period of almost ten years.

In the second phase of data recording we used the method of a layered questionnaire survey again (the four aspects considered were as follows: breakdown of the Hungarian population by regions, breakdown of the population by gender, age groups and finally school education), in which it was one thousand private persons again who responded to our questions.

Before the publication of the research findings I must point out that in the data recording of 2012-2013 the proportion of respondents from the settlement categories of 5,000-50,000 population and in excess of 50,000 inhabitants was somewhat higher than in the sample of the 2004-2005 survey, and accordingly the share of respondents from settlements with less than 5,000 inhabitants was lower in the sample of the second survey. I will repeatedly refer to this fact during the comparison of the research findings.

The interpretation of competitiveness was not restricted during the survey to the solely economic approach; competitiveness is used in a broader and more complex way, including both social and environmental aspects, and quality of life in general.

Our second survey too allowed comparability with researches previously made in the issue, on the basis of statistical data in the first place.

Issues that we looked at included the evaluation of the attractions of the place of residence, the making of national and regional hierarchies of settlements, the judgement of the attraction of cities considered as the most competitive by national and regional scale, potential reasons for changing the place of residence and the spatial characteristics of this, and also the assessment of the different settlement types as places of residence. This paper, as the title implies, is not more than the publication of a few partial results of the survey, which can be seen in the selection of a few topics to be discussed, on the one hand, and the narrowing down of the results to the region of South Transdanubia, on the other hand.

\section{FELHASZNÁLT IRODALOM}

Ambrus, Z., Kissné Majtényi, M., Kólyáné Sziráki, Á., Malakucziné Póka, M. (2008). Nagyvárosok összehasonlító vizsgálata, Területi Statisztika 2., pp. 136-163.

Berényi, B. E. (2009). Budapest belvárosának társadalmi megítélése egy kérdőíves felmérés tükrében, Földrajzi Közlemények 2., pp. 135-146.

Bodnár, G. (2012). Versenyképesség az Európai Unióban, Egy lehetséges megközelítés a NUTS 2-es régiók versenyképességének meghatározására, Területi Statisztika 2., pp. 146-159.

Boddy, M. (2002). Linking competitiveness and cohesion, In. BEGG, I. (ed): Urban Competitiveness. Policies for dynamic cities, The Policy Press, Bristol, pp. 33-52.

Chesire, P. (1999). Cities in Competition: Articulating the Gains from Integration, Urban Studies 36. 5-6., pp. 843-864. 
Csabina, Z., Leveleki, M. (2006). Vállalkozások Közép- és Nyugat-Dunántúlon a kistérségek gazdasági és demográfiai helyzetének és iparosodottságának tükrében, Comitatus 1-2., pp. 7-21.

Csomós, Gy. (2013). Magyarország gazdasági központjainak pozícióváltozása 1992 és 2011 között, Területi Statisztika 6., pp. 529-550.

Enyedi, Gy. (1997). A sikeres város, Tér és Társadalom 4., pp. 1-7.

Farkas, M. B. (2012). A korrigált humán fejlettségi mutató kistérségek közötti differenciáltsága Magyarországon, Területi Statisztika 3., pp. 230-249.

Grosz, A. (2011). A hazai vállalkozások innovációs és K+F-tevékenységének területi különbségei, Területi Statisztika 3., pp 211-226.

Horváth, Gy. (1998). Európai regionális politika. Budapest-Pécs, Dialóg Campus Kiadó, $501 \mathrm{p}$.

Jakobi, Á. (2010). Az információs társadalom versenyképesség komplex területi értékelési lehetőségei, Falu Város Régió 1., pp. 30-32.

Jensen-Butler, C. (1997). Competition between cities, urban performance and the role of urban policy: a theoretical framework, In. Jensen-Butler, C., Shachar, A., Weesep, J. Van (eds): European Cities in Competition, Averbury Publishing Company, Aldershot-Brookfild, pp. 3-42.

Koltai, Z. (2005). A magyarországi városok versenyképességének lakossági megítélése, Tér és Társadalom 3.- 4., pp. 23-41.

Koltai, Z. (2006). A magyar lakosság és vállalati szféra lakó-, illetve telephelyválasztásának szempontjai, Területi Statisztika 3., pp. 240-254.

Koltai, Z. (2008). Evaluation of Settlement Attractivements in Hungary, Tradecraft Review, Special Issue, pp. 67-74.

Lampertné Akócsi, I. (2010). A humán tőke versenyképessége a visegrádi országcsoport régióiban, Területi Statisztika 6., pp. 659-673.

Lengyel, I. (2003). Verseny és területi fejlödés: Térségek versenyképessége Magyarországon, JATEPress, Szeged, 454 p.

Lukovics, M. (2006). A magyar megyék és a főváros versenyképességének empirikus vizsgálata, Területi Statisztika 2., pp 148-166.

Lukovics, M., Kovács, P. (2008). Eljárás a területi versenyképesség mérésére, Területi Statisztika 3., pp 245-263.

Lukovics, M., Kovács, P. (2011). A magyar kistérségek versenyképessége, Területi Statisztika 1., pp 52-71.

Lukovics, M., Lóránd, B. (2010). A versenyképesség és pályázati forrás-allokáció kistérségi szinten, Tér és Társadalom 4., pp. 81-102.

Makra, L., Sümeghy, Z. (2010). Magyarországi városok és megyék osztályozása infrastrukturális és környezeti indikátorok alapján, Földrajzi Közlemények 2., pp. 203-215.

Makszim, Gy. (2011). A magyar megyék gazdasági fejlettségének összehasonlító elemzése a társadalmi folyamatok összefüggésében, Comitatus 6., pp. 18-27.

Molnár, B. (2006). A magyarországi kis- és középvárosok globalizációs típusai, Tér és Társadalom 4., pp. 67-83.

Nagyházi, Gy., Vanyó, P. P. (2010). A településhálózat fejlesztési koncepció városklaszterei és az ott lakók attitüdjei, Falu Város Régió 2-3., pp. 21-27.

Tánczos, T. (2010). A magyarországi kistérségek jellemzése társadalmi-gazdasági fejlettségük és fejlődésük alapján, Területi Statisztika 4., pp. 406-419.

Tóth, B. I. (2014). A hazai kistérségek vonzerejének és területi tőkéjének néhány összefüggése, Területi Statisztika 1., pp. 3-18. 
Koltai, Z

Tóth, G., Nagy, Z. (2013). Eltérő vagy azonos fejlődési pályák? A hazai nagyvárosok és térségek összehasonlító vizsgálata, Területi Statisztika 6., pp. 593-612. 